\title{
Sequence analysis of nucleoprotein gene reveals the co-circulation of lineages and sublineages of rabies virus in herbivorous in Rio Grande do Sul state, Brazil
}

\author{
Gisane L. de Almeida ${ }^{1,2}$ (D) Juliana F. Cargnelutti ${ }^{3}$ (D) Ananda S. Ries ${ }^{1} \cdot$ José C. Ferreira $^{2} \cdot$ Júlio C. A. Rosa $^{2} \cdot$ \\ Helena B. C. R. Batista ${ }^{4}$ (D) Eduardo F. Flores ${ }^{3}$ (I) Rudi Weiblen $^{3}$ (D)
}

Received: 17 August 2019 / Accepted: 10 January 2020 / Published online: 17 January 2020

(C) Sociedade Brasileira de Microbiologia 2020

\begin{abstract}
An unprecedented outbreak of rabies occurred in Rio Grande do Sul state (RS) from 2012 onward, resulting in thousands of bovine deaths, important economic losses, and posing risk to human health. This article describes a genetic analysis of 145 rabies viruses (RABV) recovered from herbivorous from RS between 2012 and 2017, based on partial sequence analysis of the nucleoprotein $(\mathrm{N})$ gene. High nucleotide $(n t)$ identity $(95.5$ to $100 \%)$ and amino acid $(a a)$ similarity $(96.7$ to $100 \%)$ were observed among the analyzed sequences. These sequences displayed a high sequence $n t$ identity/aa similarity with bovine RABV sequences (96.4-97.9\%; 98.1-100\%, respectively) and vampire bat RABV sequences (96.3-97.5\%; 97.8-99.5\%). Phylogenetic analyzes based on the $\mathrm{N}$ sequence allowed for the segregation of viruses into two distinct clusters. Cluster 1 comprised RABV sequences covering the whole studied period, whereas cluster 2 grouped a lower number of viruses from $2013,2014,2015$, to 2017. In some cases, viruses obtained from the same region within a short period of time grouped to distinct clusters or sub-clusters, indicating the co-circulation of distinct virus lineages in these outbreaks. The segregation into $s u b$ clusters was also observed for viral sequences obtained from the same region at different times, indicating the involvement of distinct viruses. In summary, partial sequence analyses revealed a high conservation of $\mathrm{N}$ protein and the circulation of two lineages and different sublineages of RABV in the region. In addition, our results confirm the suitability of $\mathrm{N}$ gene to study the genetic relationships among RABV isolates.
\end{abstract}

Keywords Rhabdoviridae $\cdot$ Neurological diseases $\cdot$ Cattle $\cdot$ Genetic characterization $\cdot$ Phylogeny

Responsible Editor: Fernando R. Spilki.

Electronic supplementary material The online version of this article (https://doi.org/10.1007/s42770-020-00226-z) contains supplementary material, which is available to authorized users.

\section{Eduardo F. Flores}

eduardofurtadoflores@gmail.com

1 Programa de Pós-graduação em Medicina Veterinária, Universidade Federal de Santa Maria, Av. Roraima, 1000, Hospital Veterinário, prédio 97, sala 126, Santa Maria, Rio Grande do Sul 97105-900, Brazil

2 Secretaria da Agricultura, Pecuária e Desenvolvimento Rural, Rio Grande do Sul, Av. Getúlio Vargas, 1384, Menino Deus, Porto Alegre, Rio Grande do Sul 90150-900, Brazil

3 Departamento de Medicina Veterinária Preventiva, Universidade Federal de Santa Maria, Av. Roraima, 1000, prédio 63A, Santa Maria, Rio Grande do Sul 97105-900, Brazil

4 Instituto Pasteur, Av. Paulista, 393, Cerqueira César, São Paulo, São Paulo 01311-000, Brazil

\section{Introduction}

Rabies is a zoonotic disease distributed worldwide, characterized by severe neurological signs of course generally fatal in domestic and wild mammals [1]. The disease is caused by rabies virus (RABV), an enveloped, single-stranded RNA virus of negative polarity, belonging to the genus Lyssavirus, family Rhabdoviridae [2,3]. The RABV genome contains genes coding for five proteins: nucleoprotein $(\mathrm{N})$, phosphoprotein $(\mathrm{P})$, matrix $(\mathrm{M})$, glycoprotein $(\mathrm{G})$, and polymerase $(\mathrm{L})$ [3]. The $\mathrm{N}$ is the main component of the helicoidal nucleocapsid that encapsidates the genomic RNA and plays a role in the temporal transition between transcription and replication of the viral genome during the replicative cycle [4]. The nucleotide $(n t)$ sequence of protein $\mathrm{N}$ gene is highly conserved among field RABV isolates and, as such, has been largely used for genetic identification of viral lineages, sublineages, and variants [5-17]. 
RABV is perpetuated in nature through cycles of infection involving terrestrial carnivores and bats. In South America, the hematophagous bats Desmodus rotundus are the main reservoirs and sources of RABV to herbivorous [18]. Cattle and horses are frequent targets for $D$. rotundus feeding and, as such, constitute the main herbivorous species affected by rabies [19]. The control of rabies in endemic areas is based on systematic vaccination of susceptible species and control of bat populations [20, 21].

Historically, rabies has affected bovine herds from several Brazilian regions, leading to significant economic losses to the livestock industry [22]. Official data indicates the occurrence of 37.049 cases of rabies in cattle between 1999 and 2017 in the country. In Rio Grande do Sul state (RS), the southernmost Brazilian state, hundreds of cases have been reported in cattle every year, in addition to countless unreported cases. Official data reported 1990 cases of bovine rabies from 2005 to 2017 [23]. In the last years, in addition to a crescent number of cases, bovine rabies has spread out and extended its geographical range reaching out areas otherwise free of the disease, including neighbor countries as Uruguay and Argentina [24]. The high incidence and the geographical spread of rabies have resulted in drastic economic losses to the cattle industry in the affected regions. In addition, the zoonotic potential of RABV requires that people exposed to affected animals search for medical assistance and, frequently, need to be submitted to post-exposure treatment [25]. Official data indicate that 334,956 anti-rabies medical appointments were performed in RS from 2007 to 2017 [26].

Molecular and phylogenetic analysis of RABV isolates involved in field outbreaks have become an important tool to determine the origin of the viruses and to understand the temporal and spatial patterns of dissemination/dispersion of colonies of vampire bats $[13,27,28]$. The information gathered from some studies has helped to predict future occurrence of cases and, thus, has allowed for the adoption of prevention and control measures $[9,29]$. In general, studies of RABV phylogeny and dispersion have been performed through analysis of the complete $\mathrm{G}$ gene, G-L intergenic region, and/or partial or complete analysis of $\mathrm{N}$ gene $[9,30]$. In this sense, the $\mathrm{N}$ gene has been the preferred target for sequence analysis, since it is the most conserved gene among Lyssaviruses [31].

Very little information is available on the RABV isolates associated with the recent outbreak reported in RS. The available information is restricted to a few studies analyzing a limited number of viruses, usually originated from restricted areas or outbreaks [29, 32-34]. Thus, the present study aimed at analyzing the $\mathrm{N}$ sequences from RABV associated with herbivorous rabies in RS between 2012 and 2017 ( 77 from this study and 68 obtained from GenBank), trying to identify viral lineages and/or sublineages and to determine possible phylogenetic relationships among the circulating viruses.

\section{Material and methods}

This study included brain samples of cattle $(n=74)$, horses $(n=2)$, and sheep $(n=1)$ from 72 farms located in RS. The samples were submitted to the Virology Section of the Federal University of Santa Maria (SV/UFSM), central RS, and to the Instituto de Pesquisas Desidério Finamor (IPVDF), Eldorado do Sul, metropolitan RS region, for diagnosis of rabies between 2012 and 2017. All included samples had been tested positive for RABV in a direct fluorescent antibody test (FAT) and by mouse inoculation test. RABV-positive samples were stored at $-20{ }^{\circ} \mathrm{C}$ until testing. In addition to the produced sequences, 68 sequences originated from other studies deposited in GenBank $(29,33,34)$ were included in the analysis, totalizing 145 sequences from RS.

Fragments of the cortex, hippocampus, thalamus, and medulla of RABV-positive brains (approximately $100 \mathrm{mg}$ ) were macerated and submitted to RNA extraction using Trizol® reagent (Thermo Fischer Scientific, Waltham, Massachusetts, USA) according to the manufacturer's instructions. Total RNA was diluted in $40 \mu \mathrm{L}$ of water DNAse, RNAse, and pyrogen-free. Total RNA $(6 \mu \mathrm{L})$ was submitted to in vitro transcription for cDNA synthesis, using the reverse transcriptase enzyme from GoScript ${ }^{\mathrm{TM}}$ Reverse Transcriptase (Promega Corporation, Madison, Wisconsin, USA). Following cDNA synthesis, the products were submitted to a PCR for amplification of a segment within the $\mathrm{N}$ protein gene coding sequence. The partial N gene (1284 nt) was amplified with primers: forward ATGTAACACCTCTACAATG [35] and reverse TTGACGAAGATCTTGCTCAT [36] according to a reaction described by Carnieli Junior et al. [37]. Each reaction was performed in a volume of $50 \mu \mathrm{l}$, with $3 \mu \mathrm{l}$ of cDNA. Total RNA extracted from RABV negative and positive bovine brains were used as controls.

PCR products were resolved in a $1.5 \%$ agarose gel stained by Gel Red® (Biotium, Hayward, CA, USA) and visualized under UV light after electrophoresis (70 V, $25 \mathrm{~min}$ ). For $n t$ sequencing, PCR products were purified using QIAquick Purification Kit (Qiagen, Hilde, German). Positive samples were sequenced in duplicates in an automatic sequencer ABI PRISM 3100 Genetic Analyzer (Applied Biosystems, Foster City, CA), using BigDye reagent. The sequences were analyzed by Staden program [38] to obtain the consensus sequence. The partial $\mathrm{N}$ sequence was determined using the complete RABV $\mathrm{N}$ protein sequences available in the GenBank database as model. The alignment of the sequences with sequences deposited in GenBank, including nine from Santa Catarina, SC (a neighbor state) [34], 35 from provinces in Argentina (neighbor to RS) [39], and 12 from Uruguay (neighbor to RS) [40], was performed using the program BioEdit Sequence Alignment Editor Software suite, version 7.0.5.3 (http://www.mbio.ncsu.edu/bioedit/bioedit.html) [41]. Phylogenetic analyses was performed in the Molecular 
Evolutionary Genetics Analysis (MEGA) software X [42], using the method Maximum Likelihood with the model of substitution General Time Reversible (GTR) [43], and the confiability was evaluated with bootstrap of 1.000 repetitions. The sequences were grouped in clusters and sub-clusters through topology analyses.

The data from the rabies cases from RS (species, origin/ location, year, etc.) were obtained from SV/UFSM files, IPVDF files, Sistema de Defesa Agropecuária of SEAPDR, and from the literature. The information of the additional sequences was obtained from the literature. The geographic mapping of rabies cases and sequences was performed in Microsoft $\AA$ Excel (2016). Additional information on the analyzed sequences are available on Online Resource 1.

\section{Results}

\section{Sequence analysis of $\mathbf{N}$ protein gene coding region}

The use of primers forward ATGTAACACCTCTACAATG [35] and reverse TTGACGAAGATCTTGCTCAT [36] allowed for the amplification of part of the $\mathrm{N}$ gene (1.284 $\mathrm{nt}$ - residues 67 to 1350) of 77 brain specimens. The alignment of sequences produced in the present study $(n=77)$ with sequences deposited in GenBank ( $n=68$ ) demonstrated the presence of several $n t$ changes comparing to the standard RABV CVS-PV (GenBank access number M13215). Some of these changes were aleatory/random, whereas others were frequently identified in each cluster or sub-cluster. Nt changes in 163 sites distributed randomly over the $\mathrm{N}$ coding region were present in all examined sequences, distinguishing them from the standard RABV CVS-PV, a RABV originated from carnivorous/dogs. Nonetheless, some $n t$ changes were consistently detected according to determined clusters and sub-clusters and, eventually, determined the segregation of the viruses in the phylogenetic tree (Online Resources 2 and 3). As a whole, most $n t$ changes did not result in amino acid (aa) substitutions, with exceptions of sequences of sub-clusters $1 \mathrm{a}-1 \mathrm{~d}$ and $1 \mathrm{~h}$, which presented $a a$ changes at residue 50 (Asn $\rightarrow$ Ser).

The $n t$ identity among the sequences varied from 95.5 to $100 \%$ and was also high when these sequences were compared with a bovine RABV (96.4 to $97.8 \%$; GU592649) and with a $D$. rotundus RABV (96.3 to $97.5 \%$; GU592648). The $n t$ identity dropped to 83.2 to $84.4 \%$ when comparing these sequences with a domestic carnivore RABV $\mathrm{N}$ sequence (KX148217) (Table 1).

The $n t$ sequences converted into predicted $a a$ resulted in a sequence of 428 residues (residues 23 to 450). The residue position related to RABV virulence in protein $\mathrm{N}$ was determined according to Masatani et al. [44, 45] and Shimizu et al. [46] and revealed a high conservation of $\mathrm{N}$ sequence among the field RABV viruses, noticeably in residues involved in virulence. The $a a$ similarity of the analyzed region varied from 96.7 to $100 \%$. A high similarity was observed between these sequences and a bovine RABV (98.1 to $100 \%$; GU592649) and a D. rotundus RABV deposited in GenBank (97.8 to 99.5\%; GU592648). A high similarity was also observed with a domestic carnivore RABV sequence (94.6 to $96.4 \%$; KX148217) (Table 1). No a a mutation was observed in the residues of $\mathrm{N}$ protein putatively involved in RABV virulence: 273 (Phe), 394 (Tyr), and 395 (Phe) [44-46]. Sequences grouped in sub-clusters $1 \mathrm{a}$ to $1 \mathrm{~d}$ and $1 \mathrm{~h}$ presented a consistent change at residue $50($ Asn $\rightarrow$ Ser $)$ (Online Resource 4).

\section{Phylogenetic analysis and geographical distribution}

The phylogenetic tree built based on $\mathrm{N}$ gene demonstrated that all sequences analyzed herein grouped with sequences from herbivorous and vampire bats deposited in GenBank and apart from sequences from carnivores and other wild animals. The herbivorous lineage segregated into two clusters (1 and 2), harboring sub-clusters (Figs. 1 and 2). This clustering reflected the $n t$ changes observed, in which 11 mutations were present in all sequences from cluster 1 , and 25 mutations were present in cluster 2 (Online Resources 1 and 2).

Cluster 1 grouped all viruses from 2012 to 2016 and several sequences from 2013, 2014, 2015, to 2017. Cluster 2 grouped a lower number of sequences from 2013, 2014, 2015, to 2017, originated from specific RS regions: Porto Vera Cruz and Esperança do Sul (northwestern RS mesoregion), Jaguari and São Pedro do Sul (central-eastern RS mesoregion), and Rolante, Gravataí, Glorinha, Sapiranga, Novo Hamburgo, and Três Cachoeiras (metropolitan mesoregion). These findings indicate that viruses from this cluster may have derived from a common ancestor, different from cluster 1 viruses. All sequences from SC and

carnivore RABV sequence (GenBank access KX148217), bovine RABV sequence (GU592649), Desmodus rotundus RABV sequence
Table 1 Nucleotide and amino acid identity in the partial sequence of nucleoprotein of RABV recovered from cases of rabies in herbivorous species in Rio Grande do Sul state, Brazil, compared to domestic

\section{(GU592648) and among the sequences this study}

\begin{tabular}{lllll}
\hline Identity (\%) & Domestic carnivore RABV & Bovine RABV & Desmodus rotundus RABV & Among the sequences \\
\hline Nucleotide & 83.2 to 84.4 & 96.4 to 97.8 & 96.3 to 97.5 & 95.5 to 100 \\
Amino acid & 94.6 to 96.4 & 98.1 to 100 & 97.8 to 99.5 & 96.7 to 100 \\
\hline
\end{tabular}




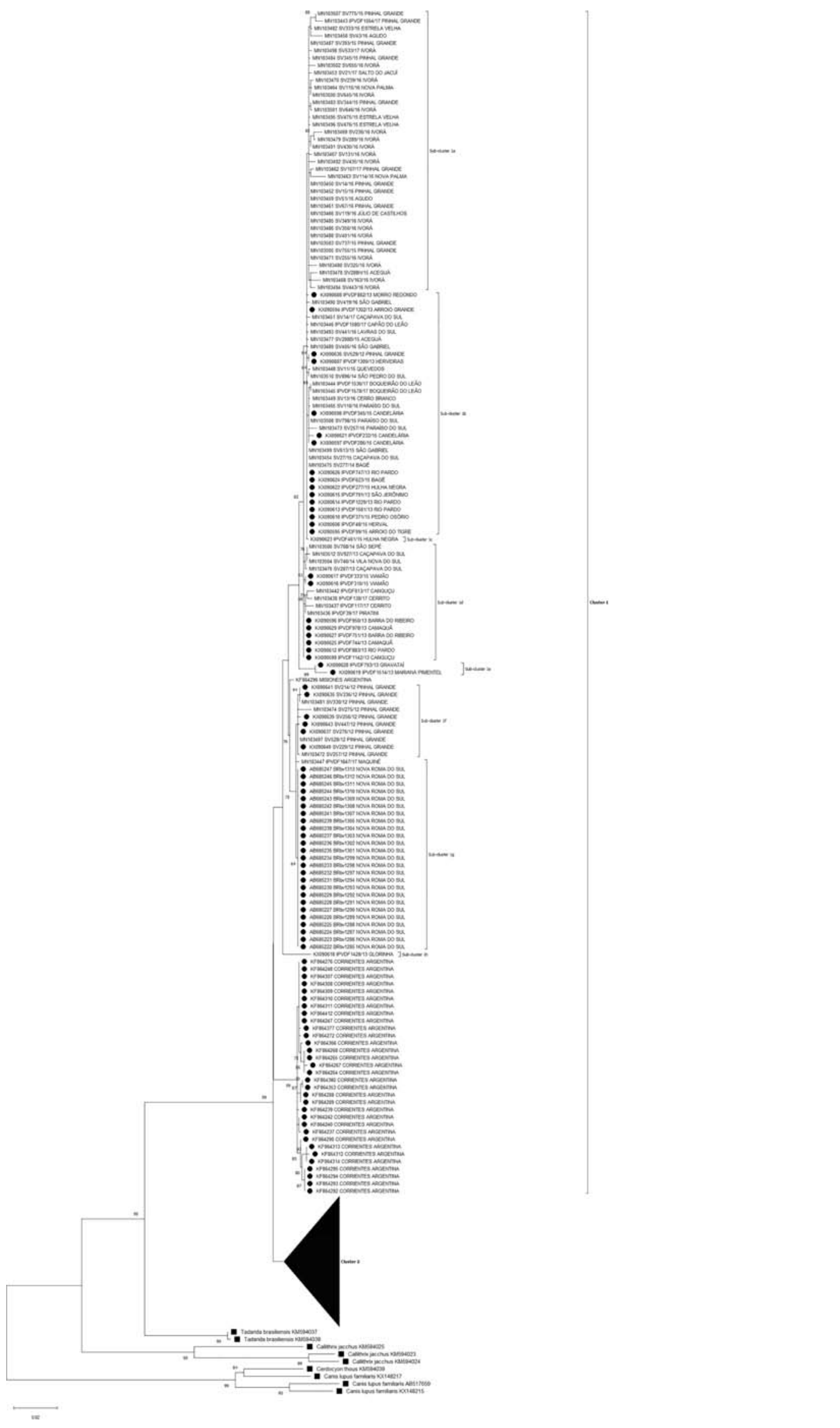


4Fig. 1 Phylogenetic tree with Cluster 2 compressed constructed by the Maximum Likelihood method with the General Time Reversible (GTR) substitution model of RABV N gene partial sequences recovered from herbivores in the state of Rio Grande do Sul, Brazil (• RABV from herbivores and vampire bats obtained from GenBank; RABV from carnivores and wild animals obtained from GenBank)

Uruguay and two sequences from Argentina grouped in cluster 2. The rest of Argentinean sequences grouped in cluster 1 . Figure 3 shows the geographical distribution of the 145 analyzed sequences, according to the respective clusters, along with 770 out of 808 cases of rabies $(87.5 \%)$ diagnosed in herbivorous in RS from 2012 to 2017.

In some cases, viruses from the same county/municipality obtained within a short period of time ( 0 days to 2 months) grouped to different clusters or sub-clusters as observed in sequences from Gravataí/2013 (KX090628) and Glorinha/ 2013 (KX090618), which grouped in cluster 1, whereas the others (KX090603, KX090602, KX090604, KX090605, and KX090601) belonged to cluster 2. This segregation was also observed in viruses from São Pedro do Sul/2014 in which one sequence (MN103510) grouped to cluster 1 and the other two (MN103509 and MN103511) with cluster 2.

The segregation of viruses originated from the same location in a short period of time into different sub-clusters was observed in sequences from Aceguá/2015 (MN103478 in sub-cluster 1b and MN103478 in sub-cluster 1a), Gravataí/2013 (KX090603 and KX090604 in sub-cluster 2b and KX090605 in sub-cluster 2d), Hulha Negra/2015 (KX090622 in sub-cluster 1b and KX090623 in sub-cluster 1c), Pinhal Grande/2012 (KX090636 in sub-cluster 1b and the others in sub-cluster 1f) and Rio Pardo/2013 (KX090612 in sub-cluster 1d and the other in sub-cluster $1 \mathrm{~b}$ ). This pattern of segregation suggests that different RABV (from different bat colonies or divergent within the same colony) were probably involved in these cases/outbreaks.

This segregation was also observed for some sequences obtained in different periods in the same location. RABV sequences from Pinhal Grande/2012 grouped predominantly to sub-cluster 1f, whereas sequences from 2015, 2016 and 2017 grouped to sub-cluster 1a. Similar segregation was observed for viruses from Caçapava do Sul, which were grouped into distinct sub-clusters (2015 and 2017 in sub-cluster 1b and 2013 in sub-cluster 1d). These findings indicate that distinct RABV were involved in the cases/outbreaks occurring in these locations at different times, likely reflecting distinct RABV circulating in different bat colonies or, less likely, resulting from virus evolution.

\section{Discussion}

Sequence analysis of part of RABV N allowed for the identification of lineages and sublineages, as well their spatial and temporal circulation in RS and nearby areas between 2012 and
2017. This study included an expressive number of sequences ( $n=145$ ) originated from all RS mesoregions, differing from previous studies which analyzed a limited number of viruses from localized outbreaks and/or from restricted areas [29, 32-34].

Sequence analysis of RABV N protein has been largely used to classify/group isolates according to their genetic lineage, variant, host species, origin, and/or geographical distribution [9, 10, 14, 17]. Analysis of RABV N protein from Brazil has led to clustering the isolates into two groups, according to the host species: viruses from dogs/carnivores, belonging to the terrestrial epidemiological cycle, and vampire bats, which together with non-hematophagous bats, form the aerial cycle of the rabies in Brazil $[9,10]$. The group of viruses associated with vampire bats could be further divided/ classified in subgroups according to their geographic origin [9]. Analysis of N sequence also allowed for the identification of a group of RABV associated with non-hematophagous bats from several Brazilian regions [17].

The results presented herein confirmed the high conservation of the $\mathrm{N}$ coding sequence among field RABV isolates [35, 47]. Amino acid mutations were randomly observed among the analyzed sequences, yet these changes did not keep an evident pattern nor involved the residues associated with RABV virulence. Residues 273 [Phe], 394 [Tyr], and 395 [Phe] are involved in the evasion of the innate immunity and are important for packaging the viral genome [44 46]. A mutation in residue 50 (Asn $\rightarrow$ Ser) observed in sequences of $s u b$ clusters $1 \mathrm{a}$ to $1 \mathrm{~d}$ and $1 \mathrm{~h}$ and also in sequences recovered from GenBank might lead to structural changes of the $\mathrm{N}$ protein and, thereby, may affect the virus biology and pathogenesis [48].

The co-circulation of these RABV lineages and sublineages in RS apparently does not pose risk to the efficacy of FAT-based diagnosis since the antibodies used in such assays are generally polyclonal [49]. These reagents are able to recognize/react with different viral proteins and, as such, seem refractory to minor antigen variations as that observed in $\mathrm{N}$ residue 50 (Asn $\rightarrow$ Ser). On the other hand, FAT assays based on monoclonal antibodies (MAbs) and molecular-based techniques are more prone to failure when used in studies applied to an antigenic/genetic diverse population of viruses [50]. Fortunately, this is not apparently the case.

An interesting finding from the phylogenetic analysis was the segregation of viral sequences from the same location in different sub-clusters according to time. These findings indicated that different RABV lineages were associated with outbreaks occurring at different times in the same locations. A given virus associated with an outbreak in 2012 may have suffered mutations with time, and/or, more likely, a distinct virus may have been introduced in the region by arrival of new bat colonies [20, 27, 29].

In addition to viral divergence observed with time, some viruses recovered from the same area within a short period 

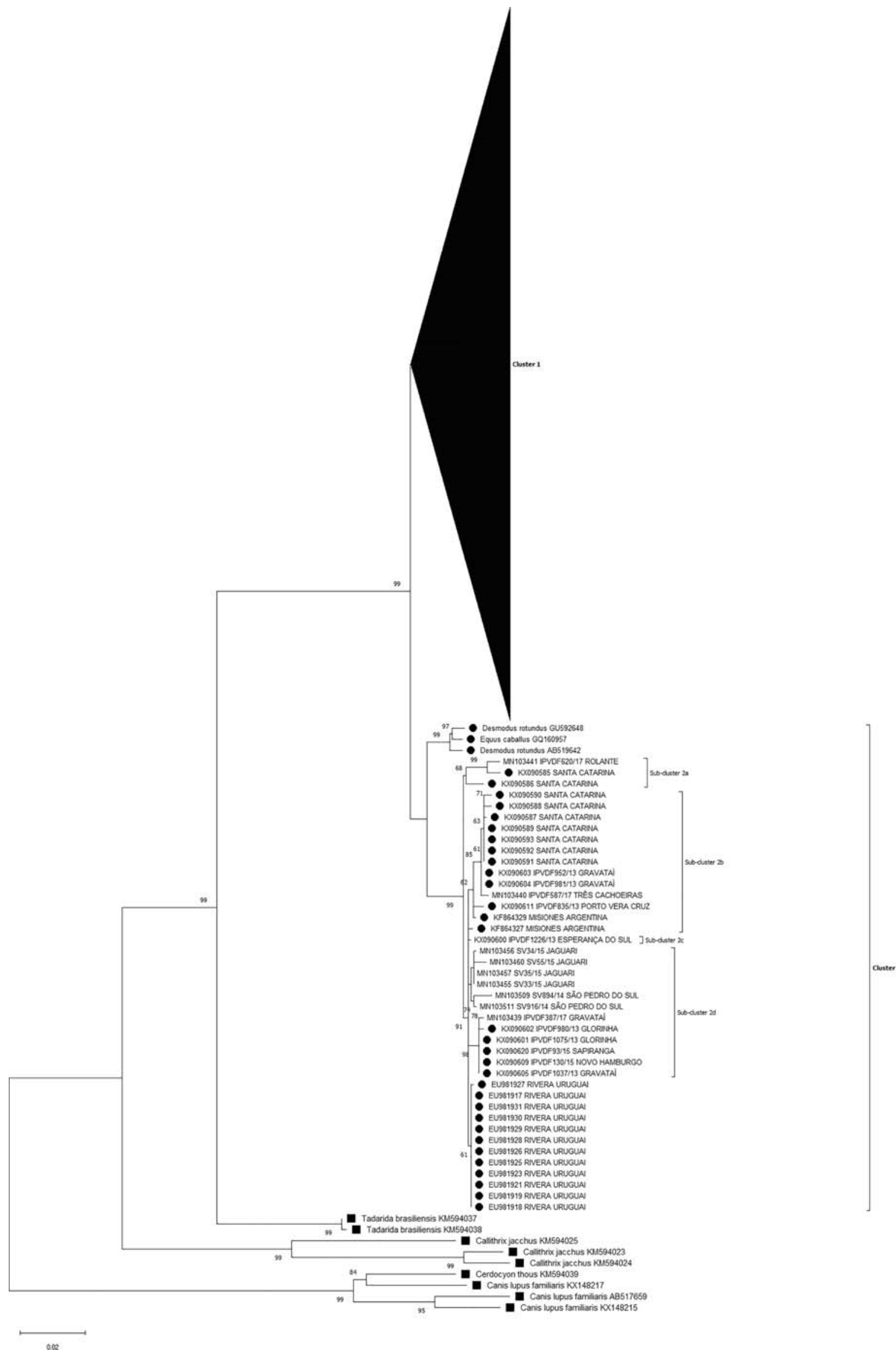
Fig. 2 Phylogenetic tree with Cluster 1 compressed constructed by the Maximum Likelihood method with the General Time Reversible (GTR) substitution model of RABV $\mathrm{N}$ gene partial sequences recovered from herbivores in the state of Rio Grande do Sul, Brazil (• RABV from herbivores and vampire bats obtained from GenBank; RABV from carnivores and wild animals obtained from GenBank)

(days to months) segregated to distinct clusters or subclusters. These findings indicate a co-circulation of different viral variants in the same region, sharing the same or nearby shelters and/or bat colonies, as described previously in the central mesoregion [29]. On the other hand, the same lineage of RABV may be involved in different outbreaks occurring in the same region in a short period, as described previously in the northeast mesoregion [33].

The identification of two clusters and their sub-clusters of the vampire bat RABV lineage demonstrates their cocirculation in RS in the examined period. These lineages may have been originated from distinct bat colonies or, alternatively, may have been maintained concomitantly along time in the same bat colonies [29]. These findings reinforce that the development of efficient strategies for the control of bat colonies depends upon the understanding of the dynamics of virus transmission within and between colonies [51]. The efforts for virus elimination or mitigation should be, therefore, coordinated spatially aiming at defining the dynamics of virus transmission within enzootic regions [52].

The present study included sequences obtained from 48 counties, covering all RS mesoregions and comprising a diversity of biomes, including remains of the Atlantic forest and
Pampa biomes. This sampling covered a significant area containing many of the approximately 2600 bat shelters cataloged by the RS Official Veterinary Service and subjected to periodic control of bat populations $[54,55]$.

Co-circulation of two distinct RABV lineages in RS has already been reported by Fernandes [34] and Cargnelutti et al. [32] testing a smaller number of samples. Our data support and extend these findings indicating that these lineages are likely established in the RS ecosystem. Most of the sequences analyzed in the present study grouped in cluster 1, which presented a wide geographic distribution (Fig. 3) and were genetically related to viruses from nearby states (SC) and countries/provinces (Uruguay and Argentina). On the other hand, viruses belonging to cluster 2 showed a more restrict geographic pattern but were related to sequences from SC and from a neighbor Uruguayan province.

Sequence analysis of RABV has already been used for mapping out the geographic dispersion of isolates [9, 27, 30, 53]. Unfortunately, the data from the present study did not allow for the identification of particular dissemination patterns for each lineage/sublineage. Analysis of a larger number of samples recovered from a more comprehensive area during a longer period may be required to achieve such an intent.

Historically, herbivorous rabies related to vampire bats has been endemic in several RS regions, noticeably those presenting environmental conditions to favorably shelter bat populations. Southern municipalities/counties such as Aceguá, Bagé, and Caçapava do Sul were historically free of rabies in spite of the presence of vampire bat populations. From 2011 onward,

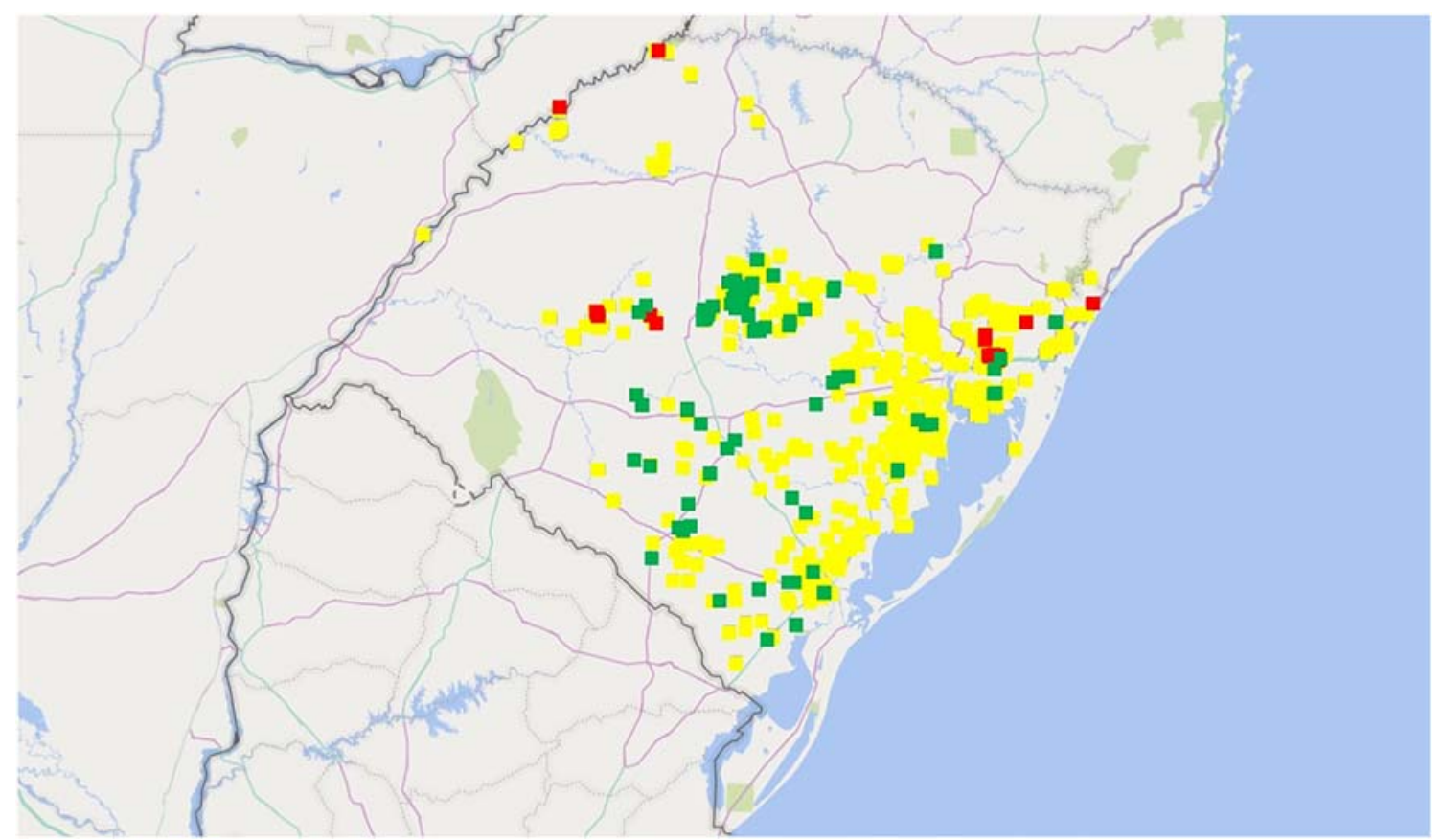

Fig. 3 Cases/outbreaks of herbivorous rabies in the state of Rio Grande do Sul, Brazil. Farms that had viruses grouped in cluster 1 in the phylogenetic tree are highlighted in green, and farms that had viruses in cluster 2 are in red. Farms where the rabies diagnosis was performed by the immunofluorescence test, biological test, or RT-PCR from 2012 to 2017 , but whose $\mathrm{N}$ sequences were not obtained are highlighted in yellow 
the occurrence of herbivorous rabies moved southward, reaching out these regions, close to the Uruguayan border (Fig. 3) [56]. Natural or manmade ecological changes occurring in the last years may have contributed for this dispersion/ dissemination, probably by affecting the behavior and dispersion dynamics of bat colonies [20].

In summary, partial sequence analysis of the $\mathrm{N}$ gene from RABV recovered from RS (2012-2017) demonstrated a high conservation of this gene/protein, indicated the co-circulation of two lineages and sublineages, and reinforced the suitability of $\mathrm{N}$ sequence to study the genetic relationships among $\mathrm{RABV}$ isolates.

Acknowledgments We thank the Secretaria da Agricultura, Pecuária e Desenvolvimento Rural do Rio Grande do Sul (SEAPDR/RS) for the leaving period conceded to GLA and for Instituto de Pesquisas Veterinárias Desidério Finamor (IPVDF) for providing some bovine brains and information concerning the viral sequences and to Nilton Rossato and Wilson Hoffmeister, coordinators of the Herbivore Rabies Control Program in Rio Grande do Sul, for their support and encouragement for this study.

Funding information EFF and RW are recipients of CNPq fellowships (Conselho Nacional de Desenvolvimento Científico e Tecnológico). This study was founded in part by the Coordenação de Aperfeiçoamento de Pessoal de Nível Superior - Brasil (CAPES) - Finance Code 001 and by Conselho Nacional de Desenvolvimento Científico e Tecnológico (CNPq) (47337/2014-9).

\section{Compliance with ethical standards}

Conflict of interest The authors declare that they have no conflict of interest.

Ethical approval This article does not contain any studies with human participants or animals performed by any of the authors.

\section{References}

1. World Health Organization (2005) WHO expert consultation on rabies: first report. https://apps.who.int/iris/handle/10665/43262. Accessed 19 July 2019

2. International Committee on the Taxonomy of Viruses (2018). Virus Taxonomy: 2018b Release. https://talk.ictvonline.org/taxonomy/. Accessed 19 July 2019

3. International Committee on the Taxonomy of Viruses. (2011) ICTV 9th Report. https://talk.ictvonline.org/ictv-reports/ictv_9th_report/ negative-sense-rna-viruses-2011/w/negrna_viruses/201/ rhabdoviridae. Accessed 18 July 2019

4. Rodriguez LL, Roehe PM, Batista HBCR, Kurath G (2017) Rhabdoviridae. In: Flores EF (ed) Virologia veterinária: virologia geral e doenças víricas, 3rd edn. Universidade Federal de Santa Maria, Santa Maria, pp 848-880

5. Batista HBCR, Caldas E, Junqueira DM, Teixeira TF, Ferreira JC, Silva JR, Rosa JCA, Roehe PM (2009) Canine rabies in Rio Grande do Sul caused by an insectivorous bat rabies virus variant. Acta Sci Vet 37(4):371-374

6. Castilho JG, Canello FM, Scheffer KC, Achkar SM, Carrieri ML, Kotait I (2008) Antigenic and genetic characterization of the first rabies virus isolated from the bat Eumops perotis in Brazil. Rev Inst Med Trop São Paulo 50(2):95-99. https://doi.org/10.1590/S003646652008000200006

7. David D, Hughes GJ, Yakobson BA, Davidson I, Un H, Aylan O, Kuzmin IV, Rupprecht CE (2007) Identification of novel canine rabies virus clades in the Middle East and North Africa. J Gen Virol 88(3):967-980. https://doi.org/10.1099/vir.0.82352-0

8. Ito M, Itou T, Sakai T, Santos MFC, Arai YT, Takasaki T, Kurane I, Ito FH (2001) Detection of rabies virus RNA isolated from several species of animals in Brazil by RT-PCR. J Vet Med Sci 63(12): 1309-1313. https://doi.org/10.1292/jvms.63.1309

9. Ito M, Yohko T, Itou AT, Sakai T, Ito FH, Takasaki T, Kurane I (2001) Genetic characterization and geographic distribution of rabies virus isolates in Brazil: identification of two reservoirs, dogs and vampire bats. Virology 284(2):214-222. https://doi.org/10. 1006/viro.2000.0916

10. Ito M, Itou T, Shoji Y, Sakai T, Ito FH, Arai YT, Takasaki T, Kurane I (2003) Discrimination between dog-related and vampire batrelated rabies viruses in Brazil by strain-specific reverse transcriptase-polymerase chain reaction and restriction fragment length polymorphism analysis. J Clin Virol 26(3):317-330. https://doi.org/10.1016/S1386-6532(02)00048-3

11. Kobayashi Y, Sato G, Shoji Y, Sato T, Itou T, Cunha EMS, Samara SI, Carvalho AAB, Nociti DP, Ito FH, Sakai T (2005) Molecular epidemiological analysis of bat rabies viruses in Brazil. J Vet Med Sci 67(7):647-652. https://doi.org/10.1292/jvms.67.647

12. Kobayashi Y, Ogawa A, Sato G, Sato T, Itou T, Samara SI, Carvalho AAB, Nociti DP, Ito FH, Sakai T (2006) Geographical distribution of vampire bat-related cattle rabies in Brazil. J Vet Med Sci 68(10):1097-1100. https://doi.org/10.1292/jvms.68.1097

13. Kobayashi Y, Sato G, Mochizuki N, Hirano S, Itou T, Carvalho AAB, Albas A, Santos HP, Ito FH, Sakai T (2008) Molecular and geographic analyses of vampire bat-transmitted cattle rabies in Central Brazil. BMC Res Notes 4(44):1-9. https://doi.org/10. 1186/1746-6148-4-44

14. Mochizuki N, Kawasaki H, Silva MLCR, Afonso JAB, Itou T, Ito FH, Sakai T (2012) Molecular epidemiology of livestock rabies viruses isolated in the northeastern Brazilian states of Paraíba and Pernambuco from 2003-2009. BMC Res Notes 5:32. https://doi. org/10.1186/1756-0500-5-32

15. Queiroz LH, Favoretto SR, Cunha EMS, Campos ACA, Lopes MC, Carvalho C, Iamamoto K, Araújo DB, Venditti LLR, Ribeiro ES, Pedro WA, Durigon EL (2012) Rabies in Southeast Brazil: a change in the epidemiological pattern. Arch Virol 157(1):93-105. https://doi.org/10.1007/s00705-011-1146-1

16. Romijn PC, Heide RVD, Cattaneo CAM, Silva RCF, Van Der Poel WHM (2003) Study of lyssaviruses of bat origin as a source of rabies for other animal species in the state of Rio de Janeiro, Brazil. Am J Trop Med Hyg 69(1):81-86

17. Schaefer R, Batista HBR, Franco AC, Rijsewijk FAM, Roehe PM (2005) Studies on antigenic and genomic properties of Brazilian rabies virus isolates. Vet Microbiol 107:161-170. https://doi.org/ 10.1016/j.vetmic.2005.01.023

18. Banyard AC, Hayman D, Johnson N, McElhinney L, Fooks AR (2011) Bats and lyssaviruses. Adv Virus Res 79:239-289. https:// doi.org/10.1016/B978-0-12-387040-7.00012-3

19. Belotto A, Leanes LF, Schneider MC, Tamayo H, Correa E (2005) Overview of rabies in the Americas. Virus Res 111(1): 5-12. https:// doi.org/10.1016/j.virusres.2005.03.006

20. Johnson N, Aréchiga-Ceballos N, Aguilar-Setien A (2014) Vampire bat rabies: ecology, epidemiology and control. Viruses 6(5):19111928. https://doi.org/10.3390/v6051911

21. Mayen F (2003) Haematophagous bats in Brazil: their role in rabies transmission, impact on public health, livestock industry and alternatives to an indiscriminate reduction of bat population. J Vet Med 50(10):469-472. https://doi.org/10.1046/j.1439-0450.2003.00713.x 
22. Ministério da Agricultura, Pecuária e Abastecimento do Brasil (2013) Ações de controle da raiva dos herbívoros no Brasil. http://wwwagriculturagovbr/assuntos/sanidade-animal-e-vegetal/ s a u d e-animal/programas-de-saude-animal/ DADOSRAIVAATE2015pdf Accessed 23 July 2019

23. Ministério da Agricultura, Pecuária e Abastecimento do Brasil (2019) Coordenação de Informação e Epidemiologia - Saúde Animal SIZ/CIEP/CGPZ/DSA/SDA. http://indicadores. agricultura.gov.br/saudeanimal/index.htm. Accessed 23 July 2019

24. World Organisation for Animal Health (2019) Disease distribution maps, World Animal Health Information Database (WAHIS Interface) - Version 1. http://www.oie.int/wahis_2/public/wahid. $\mathrm{php} /$ Diseaseinformation/Diseasedistributionmap. Accessed 23 July 2019

25. Ministério da Saúde do Brasil (2014) Normas técnicas de prolaxia da raiva humana. http://portalarquivos.saude.gov.br/images/pdf/ 2015/outubro/19/Normas-tecnicas-profilaxia-raiva.pdf. Accessed 23 July 2019

26. Centro Estadual de Vigilância em Saúde do Rio Grande do Sul (2018) Situação epidemiológica/dados. Raiva humana https:// wwwcevsrsgovbr/upload/arquivos/201809/18124231-dadosatendimento-antirrabico-pagina-cevs-09-2018pdf Accessed 23 July 2019

27. Carnieli P Jr, Castilho JG, Fahl WO, Véras NMC, Timenetsky MCST (2009) Genetic characterization of rabies virus isolated from cattle between 1997 and 2002 in an epizootic area in the state of São Paulo, Brazil. Virus Res 144(1-2):215-224. https://doi.org/10. 1016/j.virusres.2009.05.001

28. Velasco-Villa A, Orciari LA, Juárez-Islas V, Gómez-Sierra M, Padilla-Medina I, Flisser A, Souza V, Castillo A, Franka R, Escalante-Mañe M, Sauri-González I, Rupprecht CE (2006) Molecular diversity of rabies viruses associated with bats in Mexico and other countries of the Americas. J Clin Microbiol 44(5):1697-1710. https://doi.org/10.1128/JCM.44.5.1697-1710. 2006

29. Kanitz FA, Kowalski AP, Batista HBCH, Carnieli P Jr, Oliveira RN, Weiblen R, Flores EF (2014) Molecular epidemiology of an outbreak of bovine rabies in Central Rio Grande do Sul, Brazil, 2012. Cienc Rural 44(5):834-840. https://doi.org/10.1590/S010384782014000500012

30. Sato G, Itou T, Shoji Y, Miura Y, Mikami T, Ito M, Kurane I, Samara SI, Carvalho AA, Nociti DP, Ito FH, Sakai T (2004) Genetic and phylogenetic analysis of glycoprotein of rabies virus isolated from several species in Brazil. J Vet Med Sci 66(7):747753. https://doi.org/10.1292/jvms.66.747

31. Wunner WH (2007) Rabies Virus. In: Jackson AC, Wunner WH (eds) Rabies, 2nd edn. Academic Press, Cambridge, pp 23-69. https://doi.org/10.1016/B978-012369366-2/50004-X

32. Cargnelutti JF, Quadros JM, Martins M, Batista HBCR, Weiblen R, Flores EF (2017) Glycoprotein-G-gene-based molecular and phylogenetic analysis of rabies viruses associated with a large outbreak of bovine rabies in southern Brazil. Arch Virol 162(12):3697-3704. https://doi.org/10.1007/s00705-017-3533-8

33. Itou T, Fukayama T, Mochizuki N, Kobayashi Y, Deberaldini ER, Carvalho Adolorata AB, Ito FH, Sakai T (2016) Molecular epidemiological tracing of a cattle rabies outbreak lasting less than a month in Rio Grande do Sul in southern Brazil. BMC Res Notes 9(87). https://doi.org/10.1186/s13104-016-1898-5

34. Fernandes MES (2016) Sequenciamento e análise filogenética do gene da nucleoproteína de vírus da raiva isolados de bovinos nos Estados do Rio Grande do Sul e Santa Catarina. Dissertation, Universidade Federal do ABC

35. Bourhy H, Kissi B, Tordo N (1993) Molecular diversity of the lyssavirus genus. Virology 194:70-91. https://doi.org/10.1006/ viro.1993.1236
36. Smith JS (1995) Rabies Virus. In: Murray PR (ed) Manual of clinical microbiology, 6th edn. ASM Press, Washington, pp 997-1003

37. Carnieli P Jr, Fahl WO, Castilho JG, Oliveira RN, Macedo CI, Durymanova E, Jorge RSP, Morato RG, Spíndola RO, Machado LM, Sá JEU, Carrieri ML, Kotait I (2008) Characterization of rabies virus isolated from canids and identification of the main wild canid host in Northeastern Brazil. Virus Res 131(1):33-46. https:// doi.org/10.1016/j.virusres.2007.08.007

38. Staden R (1996) The Staden sequence analysis package. Mol Biotechnol 5:233-241. https://doi.org/10.1007/BF02900361

39. Torres C, Lema C, Gury Dohmen F, Beltran F, Novaro L, Russo S, Freire MC, Velasco-Villa A, Mbayed VA, Cisterna DM (2014) Phylodynamics of vampire bat-transmitted rabies in Argentina. Mol Ecol 23(9):2340-2352. https://doi.org/10.1111/mec.12728

40. Guarino H, Castilho JG, Souto J, Oliveira RN, Carrieri ML, Kotait I (2013) Antigenic and genetic characterization of rabies virus isolates from Uruguay. Virus Res 173(2):415-420. https://doi.org/10. 1016/j.virusres.2012.12.013

41. Hall TA (1999) BioEdit: a user-friendly biological sequence alignment editor and analysis program for Windows 95/98/NT. Nucl Acids Symp Ser 41:95-98

42. Kumar S, Stecher G, Li M, Knyaz C, Tamura K (2018) MEGA X: Molecular Evolutionary Genetics Analysis across computing platforms. Mol Biol Evol 35:1547-1549. https://doi.org/10.1093/ molbev/msy096

43. Nei M, Kumar S (2000) Molecular evolution and Phylogenetics. Oxford University Press, New York

44. Masatani T, Ito N, Shimizu K, Ito Y, Nakagawa K, Abe M, Yamaoka S, Sugiyama M (2011) Amino acids at positions 273 and 394 in rabies virus nucleoprotein are important for both evasion of host RIG-I-mediated antiviral response and pathogenicity. Virus Res 155(1):168-174. https://doi.org/10.1016/j.virusres.2010.09. 016

45. Masatani T, Ito N, Shimizu K, Ito Y, Nakagawa K, Sawaki Y, Koyama H, Sugiyama M (2010) Rabies virus nucleoprotein functions to evade activation of the RIG-I-mediated antiviral response. J Virol 84(8):4002-4012. https://doi.org/10.1128/JVI.02220-09

46. Shimizu K, Ito N, Mita T, Yamada K, Hosokawa-Muto J, Sugiyama M, Minamoto N (2007) Involvement of nucleoprotein, phosphoprotein, and matrix protein genes of rabies virus in virulence for adult mice. Virus Res 123(2):154-160. https://doi.org/10.1016/j. virusres.2006.08.011

47. Cleveland SB, Davies J, McClure MA (2011) A bioinformatics approach to the structure, function, and evolution of the nucleoprotein of the order Mononegavirales. PLoS One 6(5):e19275. https:// doi.org/10.1371/journal.pone.0019275

48. Albertini AAV, Wernimont AK, Muziol T, Ravelli RBG, Clapier CR, Schoehn G, Weissenhorn W, Ruigrok RWH (2006) Crystal structure of the rabies virus nucleoprotein-RNA complex. Science 313(5785):360-363. https://doi.org/10.1126/science.1125280

49. World Organisation for Animal Health (2008) OIE Terrestrial Manual. Chapter 2.1.13. http://www.oie.int/fileadmin/Home/eng/ Publications \%26_Documentation/docs/pdf/2.01.13_RABIES. pdf. Accessed 23 July 2019

50. Batista HBCR, Schmidt E, Caldas E, Massunaga P, Teixeira TF, Schaefer R, Roehe PM (2008) Caracterização de amostras do vírus da raiva, isoladas nas regiões Norte e Centro-Oeste do Brasil, com anticorpos monoclonais antilissavírus. Arq Bras Med Vet Zootec 60(1):260-262. https://doi.org/10.1590/S 0102 09352008000100036

51. Haydon DT, Cleaveland S, Taylor LH, Laurenson MK (2002) Identifying reservoirs of infection: a conceptual and practical challenge. Emerg Infect Dis 8(12):1468-1473. https://doi.org/10.3201/ eid0812.010317

52. Blackwood JC, Streicker DG, Altizer S, Rohani P (2013) Resolving the roles of immunity, pathogenesis, and immigration for rabies 
persistence in vampire bats. Proc Natl Acad Sci U S A 110(51): 20837-20842. https://doi.org/10.1073/pnas.1308817110

53. Carnieli P Jr, Castilho JG, Fahl WO, Véras NMC, Carrieri ML, Kotait I (2009) Molecular characterization of rabies virus isolates from dogs and crab-eating foxes in Northeastern Brazil. Virus Res 141(1):81-89. https://doi.org/10.1016/j.virusres.2008.12.015

54. Secretaria da Agricultura, Pecuária e Desenvolvimento Rural do Rio Grande do Sul (2016) Relatório raiva bovina 2011 - jun 2016. http://www.agricultura.rs.gov.br/upload/arquivos/201612/ 02110534-see-relatorio-raiva-bovina-v-3.pdf. Accessed 23 July 2019

55. Wiit, AA, Hoffmeister, W (2019) O desafio do controle da população de morcegos hematófagos no Rio Grande do Sul - o papel dos Núcleos de Controle da Raiva. Informativo Técnico DDA 8(2):1-16. https://www.agricultura.rs.gov.br/upload/ arquivos/201905/07102842-it-desafio-no-controle-de-morcegoshematofagos-no-rs.pdf. Accessed 12 May 2019

56. Rodenbusch CR, Ferreira JC, Rosa JCA, Migliavacca VF, Bertagnolli AC, Peres ME, Almeida LL (2016) Spatial and temporal description of laboratory diagnosis of bovine rabies in the state of Rio Grande do Sul, Brazil. Acta Sci Vet 44:1411

Publisher's note Springer Nature remains neutral with regard to jurisdictional claims in published maps and institutional affiliations. 